東北地方を中心とした亜急性甲状腺炎の疫学的調查

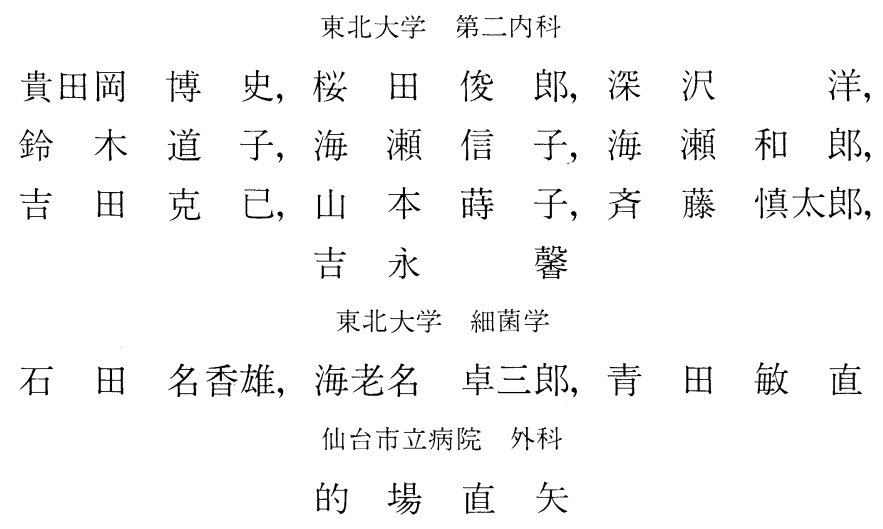

An Epidemilogical Study of Subacute Thyroiditis in Northern Japan
Hirofumi KITAOKA, Toshiro SAKURADA, Hiroshi FUKAZAWA, Michiko SUZUKI, Nobuko KAISE, Kazuro KAISE, Katsumi YOSHIDA, Makiko YAMAMOTO, Shintaro SAITO and Kaoru YOSHINAGA

The Second Department of Internal Medicine,

Tohoku University School of Medicine,

Sendai, Japan
Nakao ISHIDA, Takusaburo EBINA and Toshinao AOTA
The Department of Bacterilogy,
Tohoku University School of Medicine,
Sendai, Japan

\title{
Naoya MATOBA
}

The Devision of Surgery,

Sendai Municipal Hospital,

Sendai, Japan

It is difficult to study subacute thyroiditis epidemiologically since it occurs sporadically and infrequently.

Information about 1,127 cases (108 males, 1,019 females, from 1967 to 1982) of subacute thyroiditis in northern Japan was obtained through a questionnaire.

It was found that the usual age for the disease was forty, that females predominated in a ratio of $10.6: 1$, and that the prevalent month was July.

In clinical features, the frequencies of the inflammatory symptoms were high in the 
acute phase of the disease, and the frequencies of hyperthyroid symptoms increased with the progress of the disease.

According to the course of the disease (days after the onset without treatment), the patients were divided into seven subgroups, such as $1 \sim 7$ days, $8 \sim 14$ days, $15 \sim 21$ days, $22 \sim 28$ days, $29 \sim 42$ days, $43 \sim 56$ days and over 57 days, respectively.

Compared with the $1 \sim 7$ days group, the erythrocyte sedimentation rate, serum $\mathrm{T}_{4}$ and $\mathrm{T}_{3}$ concentrations in the $15 \sim 21$ days group showed a significant increase from $64 \pm$ 35 to $75 \pm 30 \mathrm{~mm} / \mathrm{h}(\mathrm{p}<0.001), 14.6 \pm 5.5$ to $17.6 \pm 5.6 \mu \mathrm{g} / 100 \mathrm{ml}(\mathrm{p}<0.001)$ and $218 \pm$ 124 to $263 \pm 109 \mathrm{ng} / 100 \mathrm{ml}(\mathrm{p}<0.05)$, respectively, but the BMR showed as insignificant increase from $20 \pm 15$ to $24 \pm 14 \%$.

The 24-hr ${ }^{131}$ I-thyroid uptake and resin sponge uptake (RSU) in the $21 \sim 28$ days group were $1.2 \pm 1.5 \%$ and $35.1 \pm 6.7 \%$, respectively; the former was significantly lower $(\mathrm{p}<0.02)$ and the latter was insignificantly higher than the values $(2.0 \pm 2.6 \%$ and $33.9 \pm$ $7.9 \%$, respectively) in the $1 \sim 7$ days group.

The recovery time in the steroid-treated group was $57.2 \pm 47.6$ days, which showed a statistically insignificant difference from $64.8 \pm 50.5$ days of the sodium salycylate-treated group.

But the recovery time of $78.2 \pm 64.9$ days in other anti-inflammatory drug-treated groups was significantly longer than that of the steroid and sodium salycylate-treated groups $(\mathrm{p}<0.001$ and $\mathrm{p}<0.05)$.

Among 9 viral diseases, such as measles, varicella, erythema infectiosum, hand-foot and mouth disease, rubella, mumps, influenza, epidemic keratoconjunctivitis and acute hemorrhagic conjunctivitis observed in northern Japan and Miyagi prefecture in the past 4 years, mumps, hand-foot and mouth disease and epidemic keratoconjunctivitis were prevalent in summer.

The monthly variation of mumps infection seemed to be fairly correlated with that of subacute thyroiditis. But there was no significant difference between the antiviral antibody titers against viruses, such as mumps, rebella and measles, measured at the first medical examination or one month later in the patients with subacute thyroiditis.

Therefore, more direct serological and virological studies are needed to make clear the etiology of the disease.

\section{緒 言}

亚急性甲状腺炎 (subacute thyroiditis, 以下本症) は, 1895年に Mygind ${ }^{1)}$ が thyroiditis acute simplexの18例を報告したのが最初の記載とされ，その後1904年にDe Quervain ${ }^{2)}$ が本症の病理学 的見地から詳細な報告をし，以来，本症はacute simple thyroiditis, non infectious thyroiditis, giant cell thyroiditis, pseudo-giant cell thyroiditis, granulomatous thyroiditis, struma granulomatosa, migratory or creeping thyroiditis 扔よびpseudotubercular thyroiditisなどの種々 の名称で呼ばれて来た。 
本症は散発的に発症し，甲状腺疾患の中でも比較的症例が少ないため，個々の医療機関単位では

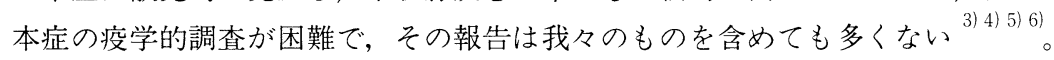

今回，我々は東北地方を中心に本症の疫学的調查を施行する機会を得たので報告する。更に，本 症と東北地方の種々ウィルス性疾患々者の発生数とを, 比較検討したので併せて報告する。

\section{対象および方法}

昭和38年から56年までに，東北六県，茨城県および山梨県の合計 34 医療機関を受診した 6 歳から 75歳までの女性1,019名, 男性108名, 合計1,127名の本症患者を対象とした。

なお，今回の疫学的調查における本症の診断の根拠は以下の如くした。

1）過去または初診時に，圧痛または自発痛のある硬い甲状腺腫を有した例。

2）過去または初診時に，急性の炎症々状のあった例。

3）一般検査で，赤沈值の克進，CRP陽性等の炎症所見を有した例。

4）甲状腺機能検查で，甲状腺ホルモン值の上昇およびヨード捸取率の著明な低下を示した例。 抗甲状腺抗体価は陽性であっても，比較的抗体価の低い例。

5）甲状腺生検にて，組織学的に確診した例。なお，これらの例のなかには，上記 1)〜 4)の診断 基準に必ずしも合致しないものもあった。

調査方法は，患者個々の発症から初診までの期間，初診時の症状，経過中にあらわれた症状，初 診時の諸検查成績, 治療方法および治療までに要した期間等をアンケート形式により各医療機関に 依頼し, その解答を集計, 検討した。

また，甲状腺機能検查のうち，血清 $\mathrm{T}_{4}$ 濃度は RIAによる測定が普及したと思われる昭和 53 年度 以後の例について検討した。

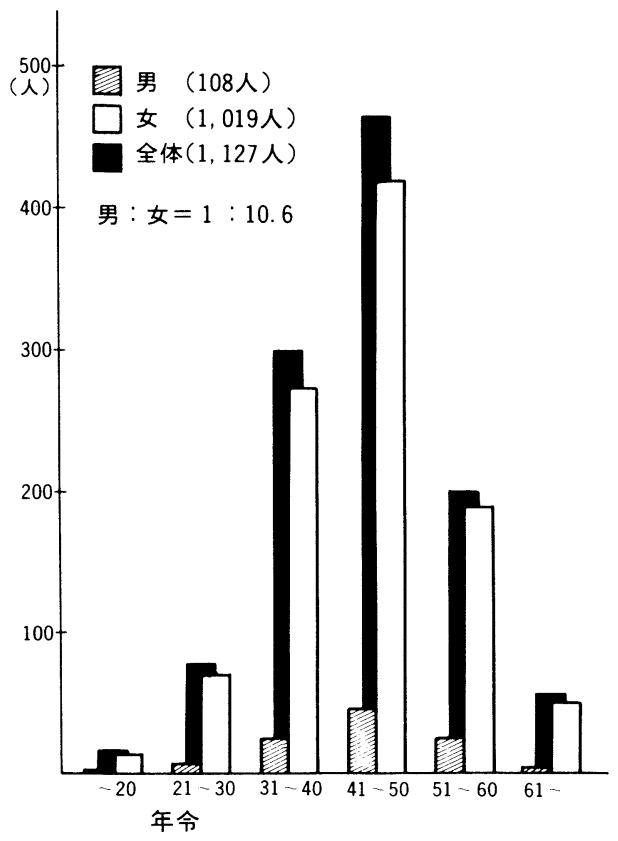

図1．年齢別による亜急性甲状腺炎の発生頻度 
結

果

図 1 に年齢別による本症の発生頻度を示すが，40歳代が約 $42 \%(470$ 例 $/ 1,127$ 例)を占めて最も多 く, 以下 30,50 歳代の順であった。20歳未満の本症患者は $1.5 \%$ (17例/1,127例), 61 歳以上は 5.1 \% (58例/1,127例)であった。男女別にみても, 発生頻度は同様の傾向を示していた。男女の比率 は1:10.6であった。

本症患者の月別発生頻度についてみると, 図 2 に示す如く, 7 月にピークがあり, 以下 8 月, 9 月および 6 月の順に多く, 比較的気温の高い時期に発生頻度が高い傾向がみとめられたが, 12 月を 中心に冬期にも小さなピークがみとめられた。男性例に限ってみると，一定の傾向はみとめられな かった。

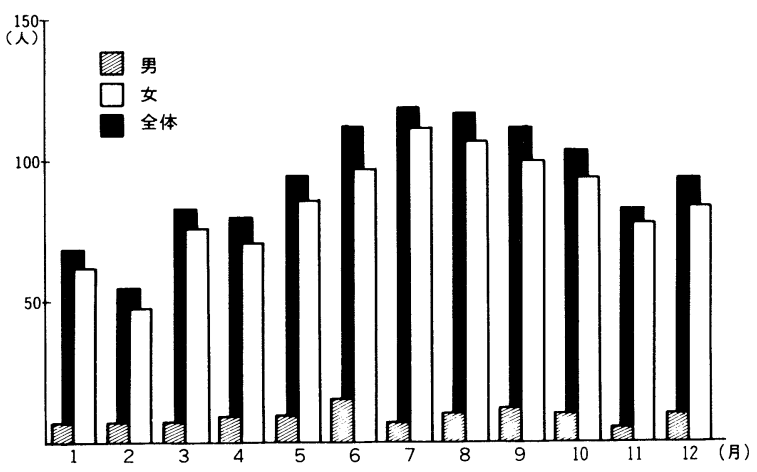

図2。亜急性甲状腺炎患者の月別発生頻度

表1。亜急性甲状腺炎の初発症状

$\begin{array}{lrc} & & \begin{array}{c}(1127 \text { 例中 }) \\ (\%)\end{array} \\ \text { 頸部痛 } & 731 & 64.9 \\ \text { 甲状腺腫 } & 488 & 43.3 \\ \text { 発熱 } & 371 & 32.9 \\ \text { 感冒様症状 } & 305 & 27.1 \\ \text { 咽頭痛 } & 282 & 25.0 \\ \text { 全身倦怠感 } & 153 & 13.6 \\ \text { 頭痛 } & 99 & 8.8 \\ \text { 動悸 } & 74 & 6.6 \\ \text { 肩こり } & 16 & 1.4 \\ \text { 嚥下困難 } & 11 & 1.0 \\ \text { 発汗 } & 9 & 0.8 \\ \text { 歯痛 } & 7 & 0.6 \\ \text { 体重減少 } & 4 & 0.4 \\ \text { 耳後放散痛 } & 3 & 0.3 \\ \text { 食欲不振 } & 3 & 0.3 \\ \text { 嗄声 } & 3 & 0.3 \\ \text { 頸部圧迫感 } & 2 & 0.2\end{array}$


本症の臨床症状についてみると, 初発症状は表 1 に示す如く, 甲状腺腫の他は, 頸部痛, 発熱, 感冒様症状㧍よび咽頭痛等の炎症々状が高頻度にみとめられたが，動悸，発汗抢よび体重減少等の 甲状腺中毒症状は，低頻度であった。一方，経過中に出現した症状（表 2 ）では，甲状腺腫が98\%の 例にみとめられ，そのうち両側が56\%，右側だけが $27.3 \%$ ，左側だけが $14.1 \%$ ，および峡部が $2.6 \%$ であった。次いで頸部の圧痛および自発痛が高頻度にみとめられた。発熱も $54.8 \%$ と高頻度であっ たが，発熱例のう ち $37^{\circ} \mathrm{C}$ 台が約70\%を占め， $39^{\circ} \mathrm{C}$ 以上の高熱は約 $8 \%$ と比較的少なかった。また， 動悸, 多汗, 体重減少および手指振戦等の甲状腺中毒症状は, 初発症状に比べ, その頻度は高くな っていた。

表2. 亜急性甲状腺炎の経過中に出現した症状

$(\%)$

\begin{tabular}{|c|c|c|c|c|c|}
\hline 甲状腺腫 & 1,105 & $(98.0)$ & 動悸 & 174 & $(15.4)$ \\
\hline 右 & 301 & $(27.3)]$ & 多汗 & 150 & $(13.3)$ \\
\hline 左 & 156 & $(14.1)$ & 体重減少 & 146 & $(13.0)$ \\
\hline 両側 & 619 & $(56.0)$ & 咽頭痛 & 128 & (11.4) \\
\hline 峡部 & 29 & $(2.6)$ & 頭痛 & 81 & $(7.2)$ \\
\hline 甲状腺腫なし & 22 & $(2.0)$ & 手指振戦 & 38 & $(3.4)$ \\
\hline 頸部圧痛 & 885 & $(78.5)$ & 息切れ & 36 & $(3.2)$ \\
\hline 頸部自発痛 & 601 & $(53.3)$ & 肩こり & 13 & $(1.2)$ \\
\hline 発熱 & 492 & $(54.8)$ & 関節痛 & 7 & $(0.6)$ \\
\hline$\lceil 37 C$ 台 & 339 & $(68.9)$ & 嗄声 & 6 & $(0.5)$ \\
\hline $38 \mathrm{C}$ 台 & 114 & $(23.2)$ & 食欲不振 & 5 & $(0.4)$ \\
\hline $39 \mathrm{C}$ 以上 & 39 & $(7.9)$ & 嚥下困難 & 2 & $(0.2)$ \\
\hline 平熱 & 406 & $(45.2)$ & & & \\
\hline 全身倦怠感 & 249 & (22.1) & 全身症状なし & 41 & $(3.6)$ \\
\hline 耳後放散痛 & 184 & $(16.3)$ & & & \\
\hline
\end{tabular}

表3. 亚急性甲状腺炎の未治療期における赤沈および甲状腺機能検查

\begin{tabular}{|c|c|c|c|c|c|c|}
\hline $\begin{array}{c}\text { 未治㞠期間十 } \\
\text { (日) }\end{array}$ & $\begin{array}{l}\text { E S R } \\
(\mathrm{mm} / \mathrm{h})\end{array}$ & $\begin{array}{c}T_{4} \\
(\mu \mathrm{g} / 100 \mathrm{~m} \ell)\end{array}$ & $\begin{array}{c}T_{3} \\
(\mathrm{ng} / 100 \mathrm{~m} \ell)\end{array}$ & $\begin{array}{c}R S \mathrm{U} \\
(\%)\end{array}$ & $\begin{array}{c}\text { B MR } \\
(\%)\end{array}$ & $\begin{array}{l}\text { 131'-uptake } \\
\text { (24hrs. \%) }\end{array}$ \\
\hline $\begin{array}{l}1 \sim 7 \\
(n=180)\end{array}$ & $\left.\begin{array}{l}64 \pm 35 \\
(n=171)\end{array}\right]$ & $\left.\begin{array}{c}14.6 \pm 5.5 \\
(n=87)\end{array}\right]$ & $\left.\begin{array}{c}218 \pm 124 \\
(n=80)\end{array}\right]$ & $\begin{array}{r}33.9 \pm 7.9 \\
(n=115)\end{array}$ & $\left.\begin{array}{r}20 \pm 15 \\
(n=74)\end{array}\right]$ & $\begin{array}{c}2.0 \pm 2.6 \\
(n=79)\end{array}$ \\
\hline $\begin{array}{l}8 \sim 14 \\
(n=227)\end{array}$ & $\begin{array}{l}75 \pm 30 \\
(n=217)\end{array}$ & $\begin{array}{r}17.1 \pm 5.1 \\
(n=116)\end{array}$ & $\begin{array}{r}259 \pm 111 \\
(n=115)\end{array}$ & $\begin{array}{r}34.1 \pm 6.6 \\
(n=138)\end{array}$ & $\begin{array}{c}23 \pm 16 \text { is } \\
(n=85)\end{array}$ & $\begin{array}{r}1.7 \pm 2.2 \\
(n=127)\end{array}$ \\
\hline $\begin{aligned} & 15 \sim 21 \\
&(n=172)\end{aligned}$ & $\begin{array}{c}79 \pm 33 \\
(n=165)\end{array}$ & $\begin{array}{c}17.6 \pm 5.6 \\
(n=86)\end{array}$ & $\begin{array}{c}263 \pm 109 \\
(n=87)\end{array}$ & $\begin{array}{c}34.4 \pm 7.1 \\
(n=104)\end{array}$ & $\begin{array}{c}24 \pm 14 \\
(n=56)\end{array}$ & $\begin{array}{c}1.6 \pm 2.7 \\
(n=118)\end{array}$ \\
\hline $\begin{aligned} & 22 \sim 28 \\
&(n=111)\end{aligned}$ & $\begin{array}{l}76 \pm 27 \\
(n=109)\end{array}$ & $\begin{array}{c}15.5 \pm 5.8 \\
(n=51)\end{array}$ & $\begin{array}{c}243 \pm 139 \\
(n=56)\end{array}$ & $\begin{array}{c}35.1 \pm 6.7 \\
(n=73)\end{array}$ & $\begin{array}{r}22 \pm 15 \\
(n=33)\end{array}$ & $\begin{array}{c}1.2 \pm 1.5 \\
(n=85)\end{array}$ \\
\hline $\begin{array}{c}29 \sim 42 \\
(n=197)\end{array}$ & $\begin{array}{l}75 \pm 33 \\
(n=191)\end{array}$ & $\begin{array}{r}15.5 \pm 5.1 \\
(n=101)^{*}\end{array}$ & $\begin{array}{c}233 \pm 85 \\
(n=94)\end{array}$ & $\begin{array}{r}32.4 \pm 5.6 \\
(n=104)\end{array}$ & $\begin{array}{r}19 \pm 14 \\
(n=93)\end{array}{ }^{*}$ & $\begin{array}{r}1.2 \pm 2.0 \\
(n=129)\end{array}$ \\
\hline $\begin{array}{r}43 \sim 56 \\
(n=68)\end{array}$ & $\begin{array}{l}66 \pm 30 \\
(n=66)\end{array}$ & $\begin{array}{c}14.6 \pm 5.4 \\
(n=29)\end{array}$ & $\begin{array}{c}224 \pm 114 \\
(n=31)\end{array}$ & $\begin{array}{c}32.2 \pm 8.2 \\
(n=39)\end{array}$ & $\begin{array}{r}19 \pm 16 \\
(n=17)\end{array}$ & $\begin{array}{c}2.2 \pm 3.6 \\
(n=40)\end{array}$ \\
\hline $\begin{array}{l}57 \sim \\
(n=80)\end{array}$ & $\begin{array}{l}55 \pm 33 \\
(\mathrm{n}=80)\end{array}$ & $\begin{array}{c}14.8 \pm 5.9 \\
(n=30)\end{array}$ & $\begin{array}{c}178 \pm 72 \\
(n=35)\end{array}$ & $\begin{array}{c}28.9 \pm 6.9 \\
(n=48)\end{array}$ & $\begin{array}{c}14 \pm 16 \\
(n=29)\end{array}$ & $\begin{array}{c}3.3 \pm 5.5 \\
(n=60)\end{array}$ \\
\hline \multicolumn{3}{|c|}{ †発症から初診までの期間 } & $\begin{array}{rl}\text { N.S. } & 1 \\
* & p \\
* * & p\end{array}$ & Sign & \multicolumn{2}{|l|}{$\begin{array}{r}* * * \\
* * * *\end{array}$} \\
\hline
\end{tabular}


表 3 に示す如く, 発症から初診までの期間 (未治療期間)を， $1-7 ， 8-14,15-21,22-28$, 29-42，43-56および57日以上の 7 群に分けて，赤沈および甲状腺機能検査について検討してみる と, 赤沈は, 未治療期間が $15-21$ 日群で $79 \pm 33 \mathrm{~mm} / \mathrm{h}$ と最も元進し，1-7 日および57日以上の群 に比べ, 有意 $(\mathrm{p}<0.001)$ に高值であった。また, 血清 $\mathrm{T}_{4}$ および $\mathrm{T}_{3}$ 濃度は, 未治療期間が 15 - 21 日 群でそれぞれ $17.6 \pm 5.6 \mu \mathrm{g} / 100 \mathrm{ml}$ および $263 \pm 109 \mathrm{ng} / 100 \mathrm{ml}$ と, いづれも未治療期間が $1-7$ 日群 および57日以上群より有意 $\left(\mathrm{T}_{4}: \mathrm{p}<0.001\right.$ おび $0.05, \mathrm{~T}_{3}: \mathrm{p}<0.02$ および 0.001$)$ に高值であっ た。 $\mathrm{T}_{3}$ 摂取率 $(\mathrm{RSU})$ は，未治療期間が $22-28$ 日群で $35.1 \pm 6.7 \%$ と最も高值で, $1-7$ 日群とは 有意差はなかったが，57日以上の群に比へ，有意 $(p<0.01)$ に高かった。基礎代謝率 $(B M R)$ は, 未治療期間が15一 21 日群で $24 \pm 14 \%$ と最も高值で， 1-7 日群と有意差はなかったが，57日以上群 に比べ，有意 $(\mathrm{p}<0.01)$ に高かった。また, ${ }^{131} \mathrm{I}$ 摂取率 (24時間值) は，未治療期間 $1-7$ 日および

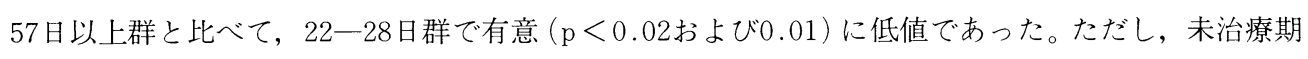
間57日以上の群でも， ${ }^{131} \mathrm{I}$ 摂取率は，なお3.3\%と，依然として低值をとっていた。

\begin{tabular}{|c|c|c|c|}
\hline \multirow{2}{*}{$\begin{array}{c}\text { 未治療期間 } \\
\text { （日） }\end{array}$} & \multicolumn{2}{|c|}{ C R } & $\mathrm{P} \quad$ (人) \\
\hline & $(-)-2(+)$ & & $3(+) \sim$ \\
\hline $\begin{array}{c}1 \sim 7 \\
(n=51)\end{array}$ & $22(43.1)$ & & $9 \quad(56.9)$ \\
\hline $\begin{array}{c}8 \sim 14 \\
(n=57)\end{array}$ & $30(52.6)$ & & $7 \quad(47.4)$ \\
\hline $\begin{array}{c}15 \sim 21 \\
(n=46)\end{array}$ & $23(50.0)$ & 23 & $3 \quad(50.0)$ \\
\hline $\begin{array}{c}22 \sim 28 \\
(n=24)\end{array}$ & $12(50.0)$ & & $2(50.0)$ \\
\hline $\begin{array}{c}29 \sim 42 \\
(n=54)\end{array}$ & $35(64.8)$ & & $9 \quad(35.2)$ \\
\hline $\begin{array}{c}43 \sim 56 \\
(n=12)\end{array}$ & $8(66.7)$ & & $4 \quad(33.3)$ \\
\hline $\begin{array}{l}57 \sim \\
(n=20)\end{array}$ & $16(80.0)$ & & $4 \quad(20.0)$ \\
\hline
\end{tabular}

表5. 亜急性甲状腺炎の未治療期における白血球数

\begin{tabular}{|c|c|c|c|c|c|c|}
\hline \multirow{3}{*}{$\begin{array}{c}\begin{array}{c}\text { 末治療期間 } \\
(\text { 日 })\end{array} \\
1-7 \\
(n=92)\end{array}$} & \multicolumn{4}{|c|}{ 白 血 球 数 } & & (人) \\
\hline & \multicolumn{2}{|c|}{ 4, 000末満 } & \multicolumn{2}{|c|}{$4,000-8,000$} & \multicolumn{2}{|c|}{8,000 以上 } \\
\hline & 4 & $(4.3)$ & 57 & $(62.0)$ & 31 & $(33.7)$ \\
\hline $\begin{array}{c}8 \sim 14 \\
(n=132) \\
\end{array}$ & 3 & (2.3) & 90 & $(68.2)$ & 39 & (29.5) \\
\hline $\begin{array}{c}15-21 \\
(n=105)\end{array}$ & 1 & $(1.0)$ & 73 & (69.5) & 31 & (29.5) \\
\hline $\begin{array}{c}22-28 \\
(n=78)\end{array}$ & 1 & $(1.3)$ & 63 & $(80.8)$ & 14 & (17.9) \\
\hline $\begin{array}{c}29 \sim 42 \\
(n=103)\end{array}$ & 2 & $(1.8)$ & 88 & $(77.8)$ & 23 & $(20.4)$ \\
\hline $\begin{array}{c}43 \sim 56 \\
(n=43)\end{array}$ & 0 & $(0)$ & 34 & $(79.1)$ & 9 & (20.9) \\
\hline $\begin{array}{c}57 \sim \\
(n=54)\end{array}$ & 3 & $(5.6)$ & 40 & (74.1) & 11 & (20.3) \\
\hline
\end{tabular}


表 4 に示す如く, 本症患者の未治療期間における CRP (C Reactive Protein) について, (一)〜 $2(+)$ の例と $3(+)$ 以上の強陽性例を比較すると, 未治療期間が長い方で, CRP強陽性例は減少し ていた。

表 5 に未治療期における白血球数について示すが，未治療期間 1-7，8-14および15一 21 日群 では, 白血球数 8,000 以上の増多を示す例が $30 \%$ 前後にみとめられたのに対し, 22 日以上の例の群 では $20 \%$ 前後に減少し, 白血球正常例が増加していた。

表6. 亜急性甲状腺炎の未治療期における甲状腺抗体

\begin{tabular}{|c|c|c|c|c|c|c|c|}
\hline \multirow{2}{*}{$\begin{array}{c}\text { 末治瘘期間 } \\
\text { (日) }\end{array}$} & & \multicolumn{5}{|c|}{$\begin{array}{c}\text { 抗 体 価 } \\
\end{array}$} & \multirow{2}{*}{$\begin{array}{c}\text { 陽性率 } \\
(\%)\end{array}$} \\
\hline & & $1<100$ & $1: 100$ & $1: 400$ & $1: 1,600$ & $1: 6,400$ & \\
\hline \multirow{2}{*}{$1-7$} & $\mathrm{MCHA}$ & 88 & 1 & 6 & 1 & 0 & 8.3 \\
\hline & TGHA & 96 & 5 & 3 & 0 & 0 & 7.6 \\
\hline \multirow{2}{*}{$8 \sim 14$} & $\mathrm{MCHA}$ & 131 & 2 & 0 & 3 & 2 & 5.1 \\
\hline & TGHA & 136 & 1 & 2 & 0 & 1 & 2.9 \\
\hline \multirow{2}{*}{$15-21$} & $\mathrm{MCHA}$ & 93 & 1 & 1 & 1 & 1 & 4.1 \\
\hline & TGHA & 96 & 1 & 0 & 2 & 0 & 3.0 \\
\hline \multirow{2}{*}{$22 \sim 28$} & MCHA & 62 & 3 & 1 & 1 & 0 & 7.4 \\
\hline & TGHA & 65 & 2 & 0 & 1 & 0 & 4.4 \\
\hline \multirow{2}{*}{$29-42$} & $\mathrm{MCHA}$ & 108 & 1 & 1 & 2 & 2 & 5.3 \\
\hline & TGHA & 106 & 1 & 2 & 0 & 0 & 2.8 \\
\hline \multirow{2}{*}{$43 \sim 56$} & $\mathrm{MCHA}$ & 33 & 2 & 0 & 0 & 0 & 5.7 \\
\hline & T GHA & 37 & 2 & 0 & 0 & 0 & 5.1 \\
\hline \multirow{2}{*}{$57-$} & $\mathrm{MCHA}$ & 43 & 0 & 2 & 0 & 1 & 6.5 \\
\hline & TGHA & 45 & 1 & 0 & 0 & 0 & 2.2 \\
\hline
\end{tabular}

表7．投与薬剂別による亜急性甲状腺の全治期間

\begin{tabular}{|c|c|c|c|c|}
\hline & & \multicolumn{3}{|c|}{ 投 与 薬 剂 } \\
\hline & & 副腎皮質ホルモン & アセチルサリチル酸 & 抗炎症剂 \\
\hline \multicolumn{2}{|r|}{$N$ (人) } & 347 & 76 & 134 \\
\hline $\begin{array}{l}\text { 全 } \\
\text { 治 } \\
\text { 期 } \\
\text { 間 }\end{array}$ & $\begin{array}{c}\text { Mean } \\
\pm \text { S.D. } \\
\text { (日) }\end{array}$ & $57.15 \pm 47.64$ & $64.75 \pm 50.54$ & $78.19 \pm 64.94$ \\
\hline \multicolumn{5}{|c|}{$\begin{aligned} & \text { N.S. : Not Significant } \\
& *: p<0.001 \\
& *: p<0.05\end{aligned}$} \\
\hline
\end{tabular}

表 6 に未治療期における甲状腺抗体について示すが，マイクロゾーム抗体 (MCHA) およびサイ ログロブリン抗体 (TGHA) の陽性率は, いづれの群でも10\%以下であり, 全体の陽性率は MCHA が $6.3 \%$, TGHA が4.1\%であった。なお，抗体価25,600倍以上の高值例は，今回の疫学的調査から 除外した。

一種類の薬剂のみによって, 治療した557例について, 投与開始から治癒までに要した期間 (全治 期間）を検討してみると（表 7 )，副腎皮質ホルモン投与患者では57.15士47.64日であり，またアセ チルサリチル酸投与患者では64.75土50.54日と，前者の方が約 7 日ほど短かったが，有意差はみと められなかった。また，抗炎症剂投与患者の全治期間は78.19土64.94日で，副腎皮質ホルモンおよ

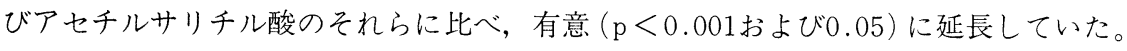


次に，東北六県におけるウィルス性疾患の発生頻度の統計学的なデー夕が得られている，昭和53 年11月から同56年12月までの本症患者数は394例 (男性40例) であり，昭和54，55および56年度の発 生数のピークは，それぞれ 8 月 (16例/107例)，6月 (25例/168例)および 5 月 (11例/100例) であ った。また，宮城県における昭和53年度から56年度までの本症患者数は，115(男性11例) であり， 昭和 $53 ， 54 ， 55$ おび56年度における発生数のピークは，それぞれ11月（4例/24例)，8月（10例/ 26例)，9月 ( 8 例 $/ 36$ 例) および 6 月 ( 5 例 $/ 29$ 例) であった。

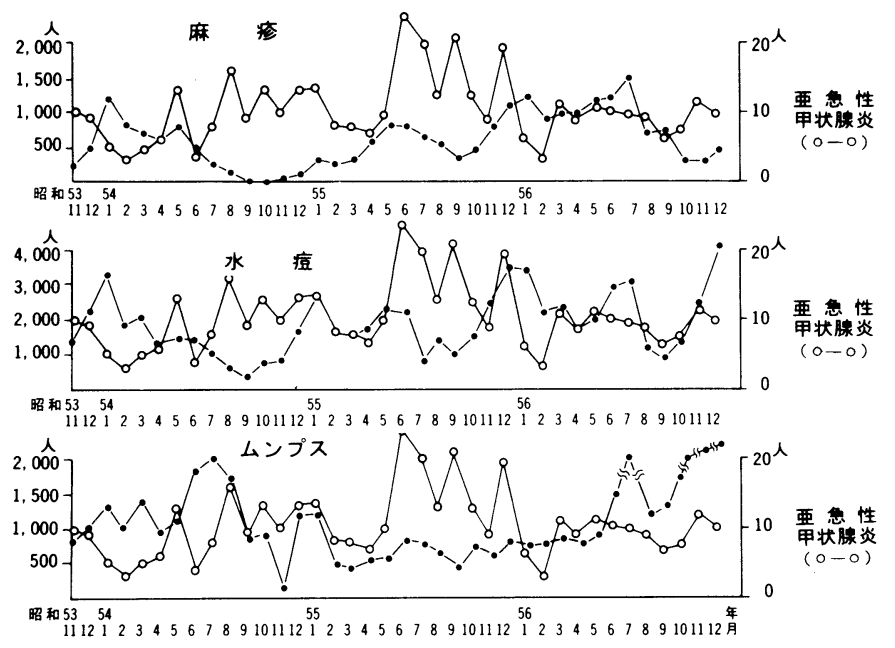

困3．東北六県における麻疹，水痘及びムンプスと恶急性甲状腺炎の 発生状況

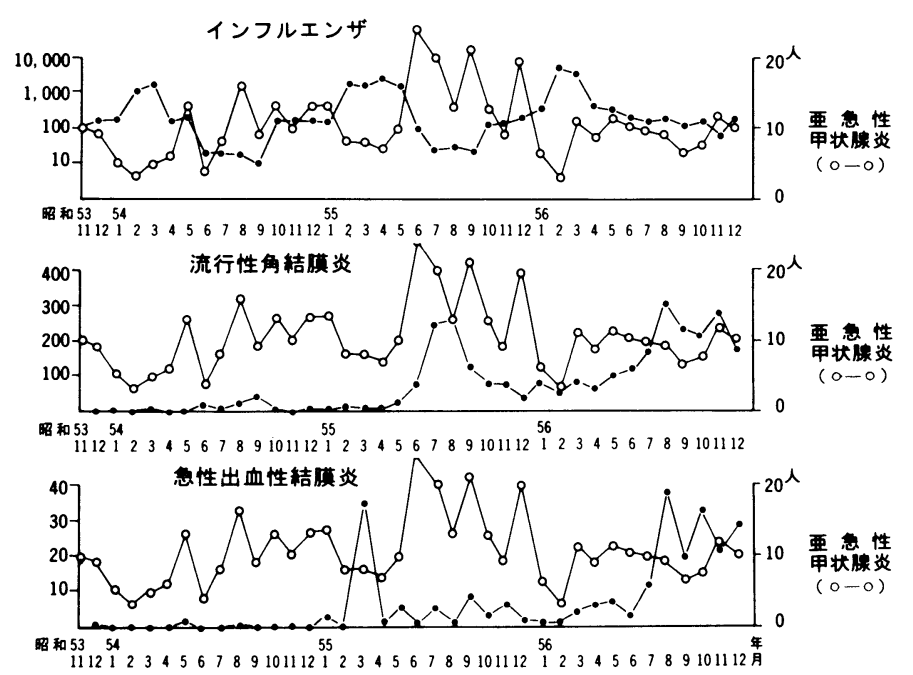

図4，東北六県におけるインフルエンザ，流行性角結膜炎及び急性出血性 結膜炎と亜急性甲状腺炎の発生状況 

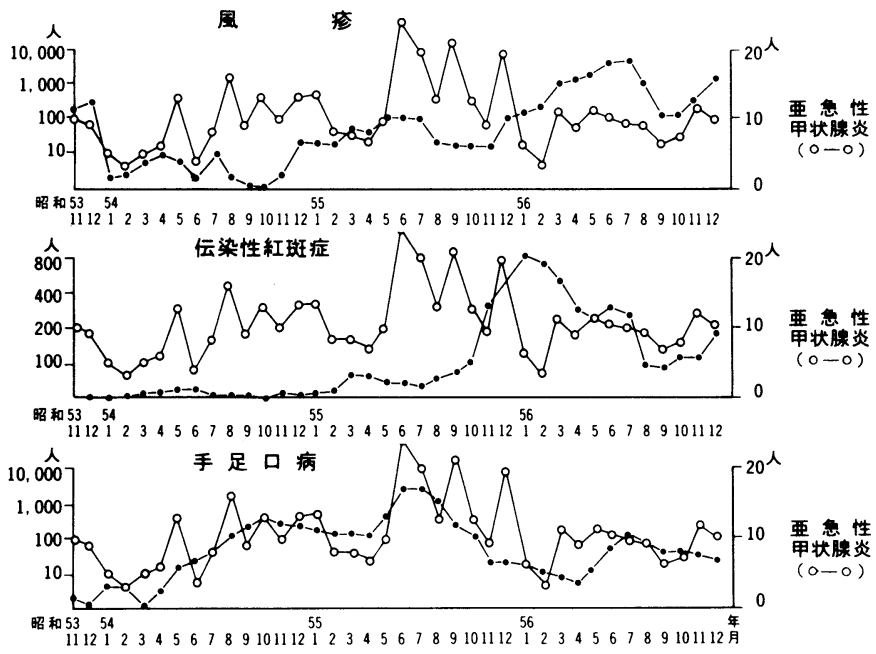

図5。東北六県における風疹，伝染性紅斑症及び手足口痛と亜急性甲状腺 炎の発生状況

一方, 東北六県における昭和 54 年度から 56 年度までのウィルス感染症 (麻疹, 水痘, ムンプス, インフルエンザ, 流行性角結膜炎, 急性出血性結膜炎, 風疹, 伝染性紅斑抒よび手足口病) の発生 状況をみると（図 $3-5$ ), 手足口病, 流行性角結膜炎扰よびムンプスは, 比較的夏季に多発する傾 向がみとめられたが, 流行性角結膜炎の各年度の発生数のピークは, 本症患者の発生数のピークよ りも, いづれも遲れてみとめられた。また, 手足口病の各年度の発生数のピークも, 本症の発生数 のピークより 1 2 ケ月遅れてみとめられた。ムンプスと本症の発生数のピークを比較してみると, 昭和54年の 5 月と 8 月および55年の 1 月にみとめられた本症患者の発生数のピークは，ムンプスの 昭和54年 3 月， 7 月および12月から 55 年 1 月にかけてのピークより，1２ 个月遅れてみとめられ た。また，昭和55年 6 月のムンプスの小さなピークは，本症患者のピークと一致してみとめられた。 しかし, 昭和56年11月にムンプスの発生数が著増しているものの, 本症発生の報告数は, それほど 多くはなかった。

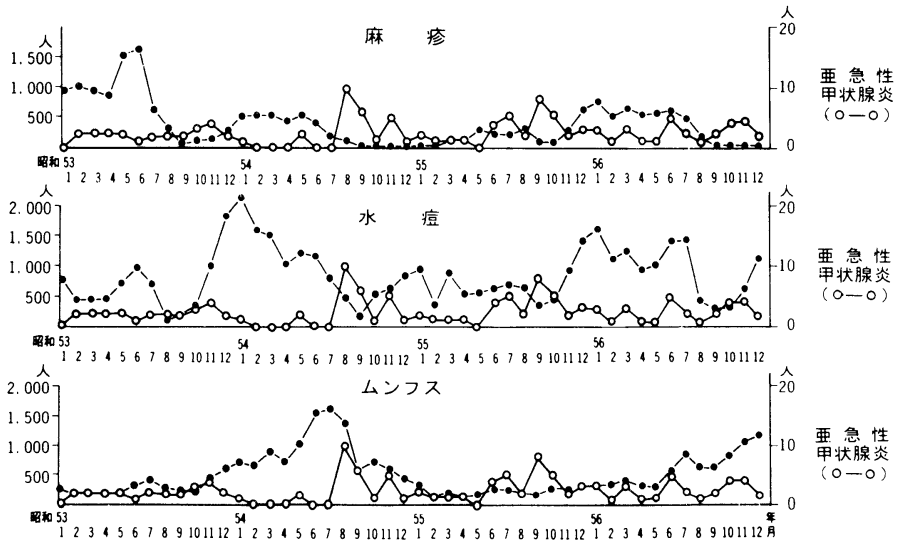

図6. 宮城県における麻疹, 水痘及びムンプスと亜急性甲状腺炎の発生状況 
他の種々ウィルス性疾患と本症と発生数の，それぞれのパターンを比較検討したが，一致するも のはなかった。

また, 宮城県におけるウイルス性疾患の昭和 53 年から 56 年度までの発生状況をみると（図 $6-8$ ), 夏季に多発する傾向のある疾患は, 風疹, 手足口病およびムンプスであった。しかし, 風疹および 手足口病の発生数のピークは本症のそれと一致しなかった。ムンプスは昭和 54 年度および56年度に 多発し，それぞれ 7 月および 12 月に発生数のピークがあり, 本症の昭和 54 年 8 月の発生数のピーク は，これより1ケ月遅れていた。昭和56年度の本症の発生報告例は必ずしも多くはなかったが， 6 月と11月のピークはムンプスのそれらとかなり近いところにあった。また，ムンプスの統計学的に 算出された発生周期と本症の発生数との関係を検討すると (困 9 ), 昭和 52 年 7 月, 53 年 11 月，54年 7 月および10月，55年 7 月および 12 月，56年 7 月および11月のものは，本症の発生数のピークと近 い関係にあるものと考えられた。

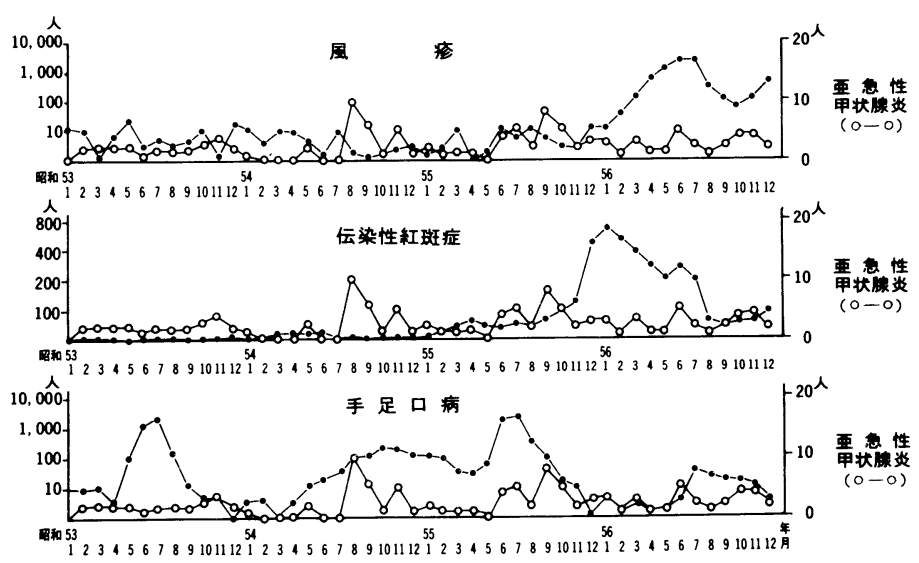

図7。宮城県におけるインフルエンザ，流行性角結膜炎及び急性出血性結 膜炎と严急性甲状腺炎の発生状況

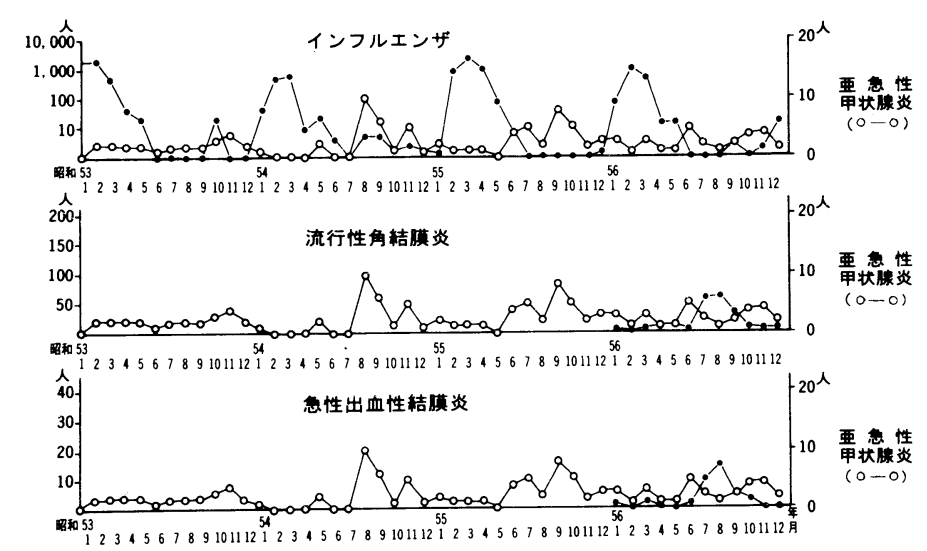

図8。宮城県に扔计る風疹, 伝染性紅斑症及び手足口病と亜急性甲状腺炎 の発生状況 


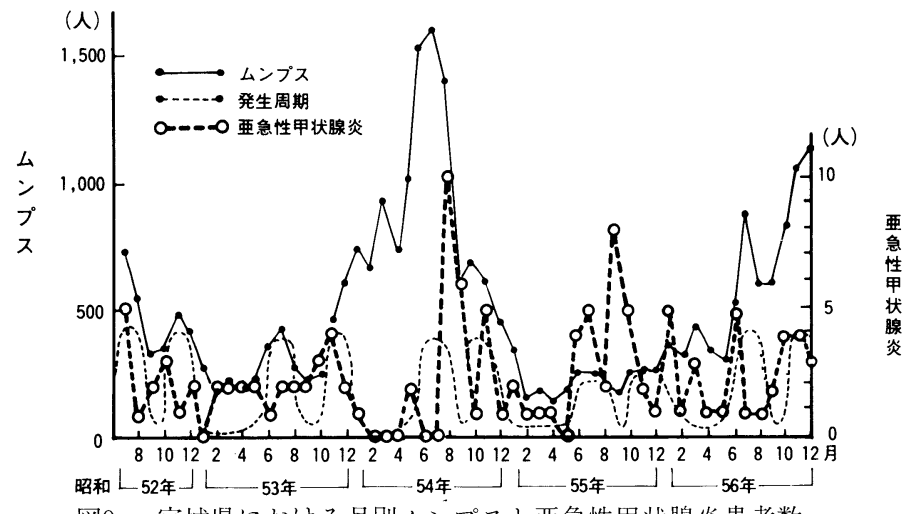

図9. 宮城県における月別ムシプスと亜急性甲状腺炎患者数

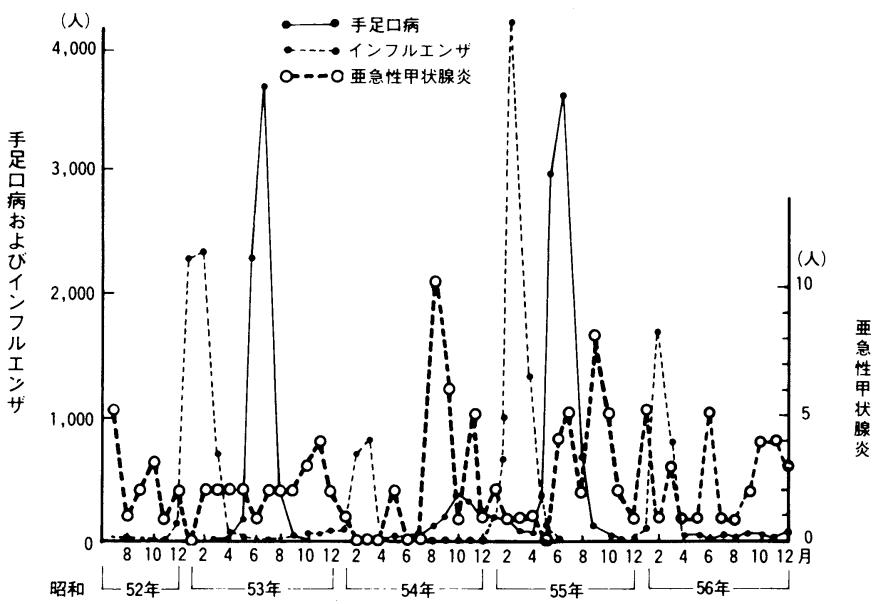

図10。宮城県における月別手足口病・インフルエンザおよび亜急性甲状腺 炎患者数

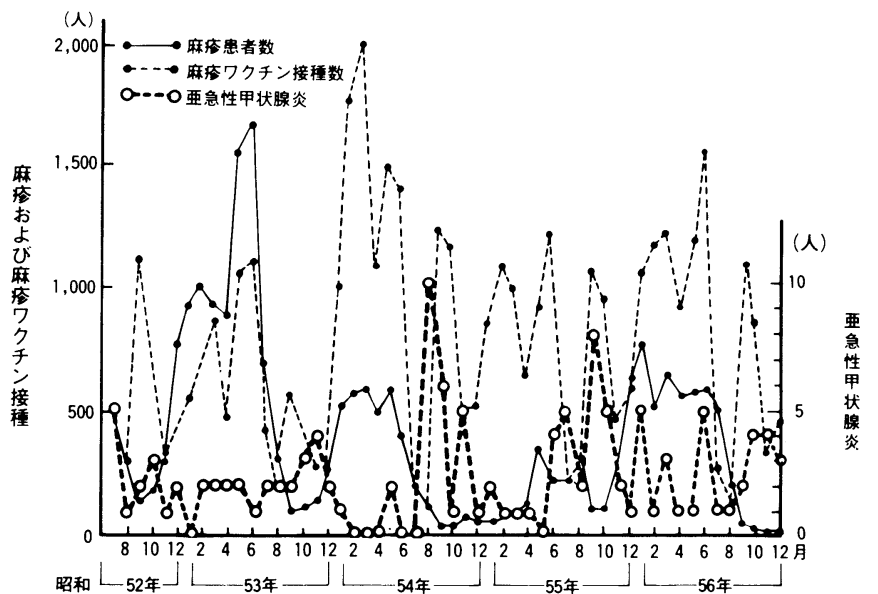

図11。宮城県における月別麻疹，麻疹ワクチン接種および覀急性甲状腺炎 患者数 


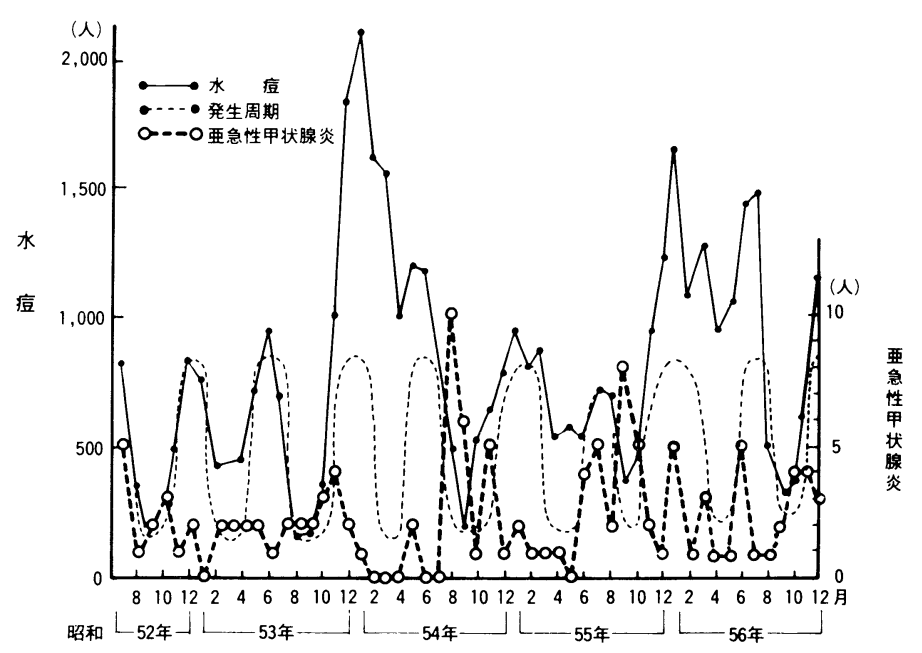

図12. 宮城県における月別水痘と亜急性甲状腺炎患者数

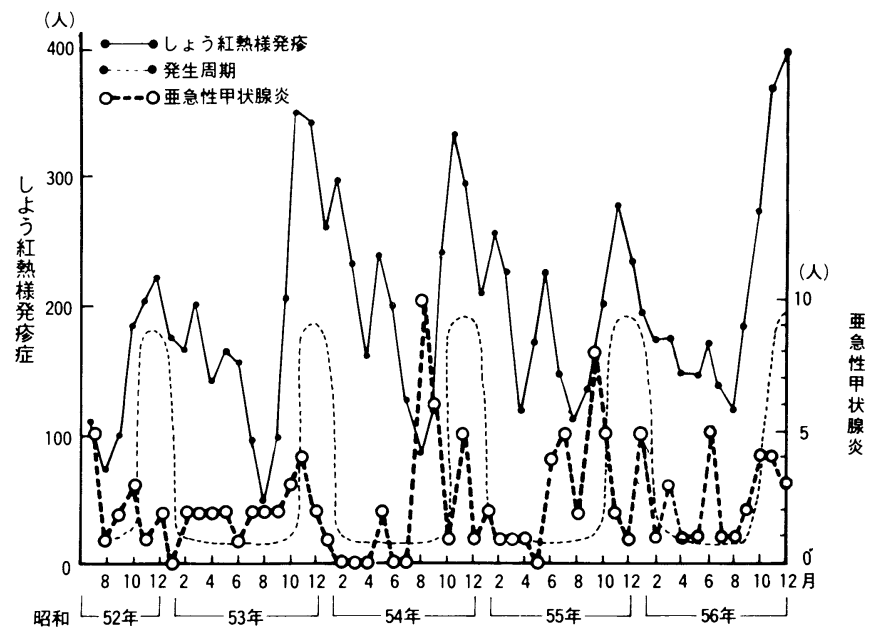

図13. 宮城県における月別しょう紅熱様発疹症と亜急性甲状腺炎患者数

宮城県におけるムンプス以外の手足口病，インフルエンザ，麻疹，しょう紅熱様発疹症および百 日咳患者において, 統計学的に算出された発生周期（図10-14）は，いづれも本症の発生数のピー クと一致する傾向を示さなかった。

本症における抗ウィルス抗体価の変動を, 急性期 (初診時) およびその約 1 ケ月後の二時期におい て検索したが (表 8)，有意の変化はみとめられなかった。 


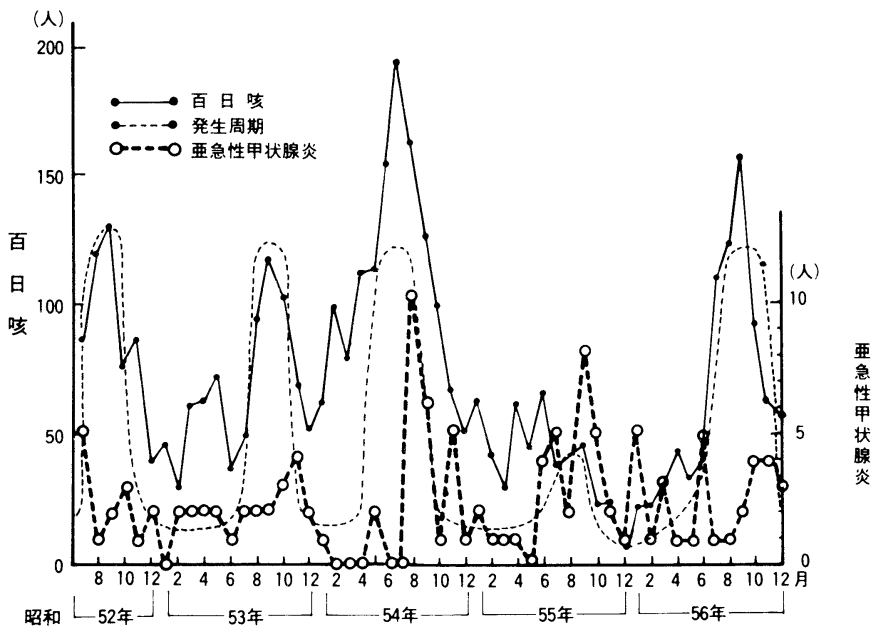

図14。宮城県における月別百日咳と亜急性甲状腺炎患者数

表8．亜急性甲状腺炎の急性期およびその一ヶ月後の抗ウ イルス抗体価

\begin{tabular}{|c|cc|c|c|c|c|c|c|}
\hline \multirow{2}{*}{ Case No. } & \multirow{2}{*}{ 年令 性 } & \multicolumn{2}{|c|}{ Mumps } & \multicolumn{2}{|c|}{ Rubella } & \multicolumn{2}{c|}{ Measles } \\
\cline { 3 - 8 } & 急性期 & 回復期 & 急性期 & 回復期 & 急性期 & 回復 \\
\hline 1 & 43 & $\mathrm{~F}$ & $<1: 8$ & $<1: 8$ & $1: 32$ & $1: 128$ & $1: 64$ & $1: 32$ \\
2 & 45 & $\mathrm{~F}$ & $<1: 8$ & $1: 8$ & $1: 16$ & $1: 16$ & $1: 8$ & $1: 8$ \\
3 & 33 & $\mathrm{~F}$ & $1: 8$ & $<1: 8$ & $1: 32$ & $1: 32$ & $<1: 8$ & $<1: 8$ \\
4 & 37 & $\mathrm{~F}$ & $<1: 8$ & $<1: 8$ & $1: 32$ & $1: 16$ & $<1: 8$ & $1: 32$ \\
5 & 34 & $\mathrm{~F}$ & $1: 8$ & $1: 8$ & $1: 8$ & $<1: 8$ & $1: 8$ & $1: 8$ \\
6 & 27 & $\mathrm{~F}$ & $<1: 8$ & $<1: 8$ & $1: 16$ & $1: 16$ & $<1: 8$ & $<1: 8$ \\
7 & 55 & $\mathrm{~F}$ & $1: 8$ & $<1: 8$ & $1: 8$ & $1: 16$ & $1: 8$ & $1: 8$ \\
8 & 38 & $\mathrm{~F}$ & $1: 16$ & $<1: 8$ & $1: 32$ & $1: 8$ & $1: 64$ & $1: 16$ \\
9 & 36 & $\mathrm{~F}$ & $<1: 8$ & $1: 8$ & $1: 32$ & $1: 32$ & $1: 16$ & $1: 8$ \\
10 & 56 & $\mathrm{~F}$ & $<1: 8$ & $1: 8$ & $<1: 8$ & $<1: 8$ & $<1: 8$ & $<1: 8$ \\
11 & 50 & $\mathrm{M}$ & $1: 8$ & $<1: 8$ & $1: 128$ & $1: 64$ & $1: 16$ & $1: 16$ \\
12 & 44 & $\mathrm{~F}$ & $<1: 8$ & $<1: 8$ & $1: 16$ & $1: 16$ & $1: 16$ & $1: 8$ \\
13 & 43 & $\mathrm{~F}$ & $<1: 8$ & $<1: 8$ & $1: 32$ & $1: 16$ & $1: 8$ & $<1: 8$ \\
14 & 35 & $\mathrm{~F}$ & $1: 8$ & $1: 8$ & $1: 32$ & $1: 32$ & $<1: 8$ & $1: 8$ \\
15 & 43 & $\mathrm{~F}$ & $<1: 8$ & $<1: 8$ & $1: 64$ & $1: 128$ & $1: 32$ & $1: 64$ \\
16 & 28 & $\mathrm{~F}$ & $1: 8$ & $<1: 8$ & $<1: 64$ & $1: 32$ & $<1: 8$ & $1: 8$ \\
\hline
\end{tabular}

考察

年齢別の本症の発生頻度は，40歳代にピークがみとめられ，次いで30歳代，50歳代の順であり， 従来の報告 ${ }^{57 \text { 7) } 81}$ と一致していた。男性例だけに限っての年齢別発生頻度の報告は, まだみとめら れていないようであるが，本調查では，やはり40歳代にピークがあり，女性例と同様の分布状態で あった。また，男女比は，従来の報告では $1: 3-7^{5)^{\text {8) }} \text { 11) }}$ とされているが，本調査では $1: 10.6$

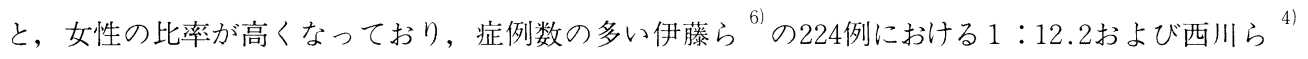
の1,061例における $1 ： 10.9$ に近い值であった。

また，本症の月別発生頻度は，7月ピークに比較的気温の高い時期に多くみとめられ，これまで の報告 ${ }^{4)}$ と一致していた。しかし，本調查では冬期にも小さなピークがみとめられた。また，男 性例に限ってみたところでは, 一定の傾向はみとめられなかったが, これは症例数の少ないことが 影響しているのではないかと考えられた。 
本症の臨床症状についてみると, 初発症状としては甲状腺腫の他は, 頸部痛, 発熱, 感冒様症状 および咽頭痛などの炎症口状が高頻度にみとめられ，動悸，多汗，体重減少および手指振戦などの 甲状腺中毒に伴う症状は低頻度であった。これに対して, 臨床経過中に出現した症状では, 甲状腺 中毒に伴う症状の頻度の方が高くなっていた。

本症の経過中の甲状腺機能の変動については, 多数の報告 ${ }^{12)}$ 18) があるが，いづれも治療経過中 のものである。今回の調查では, 同一症例の経過中の甲状腺機能の変動を検討することは出来なか つたが，未治療期間別に分けて検討してみると，血清 $\mathrm{T}_{4}$ ならびに $\mathrm{T}_{3}$ 濃度， RSU および BMRの平 均值は，15一-21日あるいは22-28日群において最も高值となり，57日以上の症例群の平均值がはじ めて正常域になっていた。これらの結果は, 経過中に出現した症状のうちで, 甲状腺中毒症状の頻 度が，初診時よりも高くなっていたことと，よく一致するものと考えられる。しかしながら，甲状 腺機能立進症患者の場合の症状発現に比べると，甲状腺ホルモン濃度が上昇している割には，その 頻度は少なく，この理由としては，我々がすでに報告したごとく ${ }^{1920)}$, 本症における $\mathrm{T}_{4} / \mathrm{T}_{3}$ 比および 遊離 $\mathrm{T}_{3}$ 值が, 甲状腺機能充進症のそれらより有意に低值であったこと, これに加えて病恼期間が 短いことなどが関係しているものと思われた。

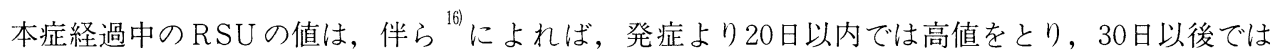
正常域に入るという。一方, 斉藤ら ${ }^{51}$ は本症におけるトリオソルブ試験の平均值は正常範囲にあった とし, 本調査においても未治療期間別にみたRSUの平均值は, 22-28日群で $35.1 \pm 6.7 \%$ と最高值 をとっていたものの正常範囲にとどまっており，後者と一致する結果であった。

本症における ${ }^{131} \mathrm{I}$ 摂取率の低下は，甲状腺濾胞上皮細胞の破壊，およびこのために甲状腺から血 中へ漏出した多量の甲状腺ホルモンによって下垂体からの TSH 分泌が抑制されていることなどが 考えられている ${ }^{9)}$ 。本調查では ${ }^{131} \mathrm{I}$ 損取率は発病より4～ 5 週後 (22-28 日群)に最低值をとったこ とから, この時期まで甲状腺における炎症が進行し，その後より修復機転が始まるのではないかと 考えられているが, 約 2 ヶ月経過した後 (57日以上の群)も ${ }^{131} \mathrm{I}$ 摂取率は，依然として低值にとど まっていた。

赤沈は，未治療期間が15一21日群において最高值をとった後，徐々に低下する傾向にあったが， 57日以上の群でも，なお中等度の六進がみとめられた。一方，CRPを，㓌性一弱陽性例 $(2(+)$ 以 下）と強陽性例（ $3(+)$ 以上）とにおいて比較してみると, 未治療期間が長い程強陽性例の頻度は低 下し, 炎症反応が消裉して来ることを示し，このことからも本症が self-limitedの炎症性の疾患で あることが示唆された。

本症患者の白血球数について, 未治療期間別にみると，61-81\%の例が正常であった。白血球増 多の例が，未治療期間 1-7，8-14および15一21日群で30\%前後にみとめられ，未治療期間がそ れ以上長くなると，20\%前後に低下していたが，統計学的には有意の差はみとめられなかった。

本症の急性期において, 一過性の種々の免疫異常がみとめられ, 血中に MCHA P TGHAが低值 ながらも現われたり ${ }^{9211}$, Immunosuppressive acid protein(IAP)の上昇がみとめられたり , 甲 状腺抗原に対するリンバ球の幼若化がみとめられたりする ${ }^{23)}$ と報告されている。本調查では, MCHA およびTGHAの陽性率は，それぞれ6.3および4.1\%と低值であった。また，本調査の本症患者25例 で測定したIAP (正常值 $500 \mu \mathrm{g} / \mathrm{ml}$ 以下) は530〜1,280 $\mu \mathrm{g} / \mathrm{ml}, 828.4 \pm 200.6 \mu \mathrm{g} / \mathrm{ml}($ mean $\pm \mathrm{SD}$ ) と全例高值をとっていた。

本症の治療に関しては, 副腎皮質ホルモンが最も有効とされ ${ }^{24)}$, アセチルサリチル酸などの鎮痛 
解熱剂やインドメサシンなどの抗炎症剤も副腎皮質ホルモンと同様，効果があることがみとめられ

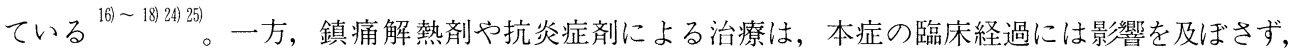
したがって，全治期間は短縮されないという 。 とした場合，副腎皮質ホルモンの全治期間は，アセチルサリチル酸のそれより約 7 日短かったが有 意の差ではなかったものの，抗炎症剤投与群の全治期間は前二者より，有意に長かった。したがっ て,アセチルサリチル酸は, 副腎皮質ホルモンと同じく本症の臨床経過に影響を及ぼしうることが 考えられた。

本症の原因としては，その臨床症状，経過抢よび検查所見から，良性のウィルス感染症が考えら れており ${ }^{7)}$, Mumpsvirus, Adenovirus, Influenxa およびCoxsackieなどのウィルスに対する抗体

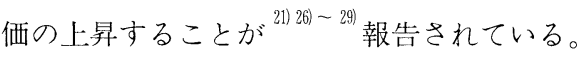

今回, 我々も宮城県および東北六県の種々のウィルス感染症と本症患者の発生状況を比較検討し てみたが，宮城県および東北六県のいづれにおいても，本症の発生状況とムンプスのそれが，比較 的関係があるように思われた。しかし，今回検討した他のウィルス性疾患においては，本症の発生 状況と近い関係にあると思われるものはみとめられなかった。

Eylan ら ${ }^{26)}$ は, Mumpsの症状のない本症患者において, Mumpsvirus抗体価の上昇がみとめられ, しかもbiopsyにより甲状腺から Mumpsvirusを証明したと報告している。本調査の結果からも Mumpsvirusが，何らかの関係があるように思われたが，初診時とその約 1 ケ月後におけるムンプス， 麻疹および風疹の抗体価には変化がみとめられず，明確な結論は得られなかった。Volpe ら ${ }^{21)}$ は本 症は，一つのウィルスよりも，むしろ何種類かのウィルスによっておこるのではないかと述べてお り，この点に関しては，更に詳細な検索を要するものと思われる。

本調査の一部は厚生省の研究費 (厚生省特定疾患「遅発性ウィルス感染」に関する研究) の援助を 受けた。

本調査に御協力頂いた下記の諸先生方に深謝いたします。

\begin{tabular}{|c|c|}
\hline 済病院 内科 & 鳥飼 \\
\hline 竹田総合病院 内科 & 橘 \\
\hline 立仙台病院 内科 & 渡辺 \\
\hline 手県立宮古病院 内科 & 橋本 \\
\hline 外科 & 八重樫 \\
\hline 県立大船渡病院 外科 & 松橋 \\
\hline 立築館病院 外科 & 岡山 \\
\hline 鹿総合病院 外科 & 松岡 \\
\hline 沢市立病院 外科 & 鈴木 \\
\hline 北大学医学部 第二外科 & 三浦 \\
\hline 和会中通病院内科 & 稲葉龍 \\
\hline 内科 & 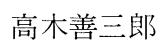 \\
\hline 病院 内科 & 飯野 \\
\hline 第一外科 & 桀 \\
\hline
\end{tabular}

鶴岡市立荘内病院 内科 奥村 浩

弘前大学医学部 第三内科 中園 誠 山形市立病院済生館 内科 佐々木康彦

同向券島一郎

同外科峯田 武雄

岩手県立中央病院 外科栗原 英夫

同第一内科 高橋 暁

福島県立医科大学第二外科 渡辺 岩雄

同第三内科 松井遵一郎

山形大学医学部 第三内科原 正雄 公立刈田総合病院 外科熊谷 暢夫 石卷赤十字病院 内科鈴木 隆城 太田給合病院 内科齐藤敬太郎 公立気仙沼総合病院 外科 大内 謙二 


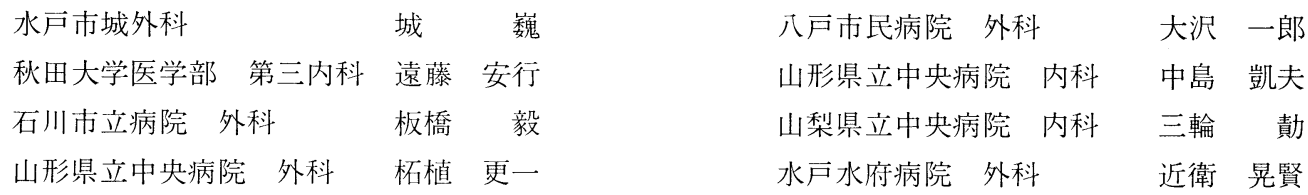

本研究の一部は第56回日本内分泌学会秋季大会において発表した。

\section{文献}

1) Mygind, H.: Thyroiditis akuta simplex. J. Laryngol. Otal., 9: 181-193, 1895.

2) De Quervain, F.: Die akute nicht eitrige Thyroiditis und die Beteiligung der Schilddruse an akuten intoxikationen und infektion Uberhaupt. Mitt. Grenzgeb. Med. Chir. (Supple. 2) Bd. 1-165, 6pt, 1904 . 3) 吉永 馨, 斉藤慎太郎, 共著: 成人病シリーズ12, 甲状腺疾 患，初診から治療まで医学図書出版株式会社，東京，1978，p.90-96. 4 4) 西川義彦, 吉田 明, 沖 卓史, 大井俊孝, 浜田 昇, 百溪尚子, 三村 孝, 伊藤国彦, 丸地信弘：亚急性甲状腺炎の臨床 疫学的研究, 日内分泌会誌, 56:1347, 1980. 5 ) 斉藤慎太郎, 桜田俊郎, 山本蒔子, 山口 徹, 鳥飼龍生：严急性甲状腺炎の臨床, 内科, 31: 152-155, 1973. 6 ）伊藤国彦：急性甲 状腺炎と严急性甲状腺炎, 内科, 44: 936-937, $1979 . \quad 7)$ Steinberg, F.U.: Subacute granulomatous thyroiditis, a review. Ann. Intern. Med., 52: 1014-1025, 1960.

8) Volpé, R.: Subacute (Nensuppurative) thyroiditis, by Werner, S.C. and Ingbar, S.H., The Thyroid, Harper \& Row, Ltd., New York, 1978.

9) Green, J.N.: Subacute thyroiditis. Am. J. Med., 51: 97-108, 1971.

10)斎藤慎太郎：急性甲状腺炎, 吉永 馨編集, 内科Mook No. 2, 甲状腺疾患, 金原出版株式会社, 東京, 1978, p.183-187.

11）斉藤慎太郎，桜田俊郎，山本蒔子：亜急性甲状腺炎，日本医事新報，2955：10-15, 1980.

12) Ogihara, T., Yamamoto, T., Azukizawa, M., Miyai, K. and Kumahara, Y.: Serum thyrotropin and thyroid hormones in the course of subacute thyroiditis. J. Clin. Endocrinol. Metab., 37: 602-606, 1973.

13) Lasen, P.R.: Serum triiodothyronine, thyroxine, and thyrotropin during hyperthyroid, hypothyroid, and recovery phase of subacute thyroiditis. Metabolism, 23: 467-471, 1974.

14) Kamino, N., Kobayashi, I., Mori, M., Uehara, T., Fukuda, H., Tsuyusaki, K., Nakamura, Y. and Kobayashi, S.: Permissive role of thyrotropin on thyroid radioiodine uptake during the recovery phase of subacute thyroiditis. Metabolism, 26: 295-299, 1977.

15) Weihl, A.C., Daniels, G.H., Ridgway, E.C. and Maloof, F.: Thyroidfunction tests during the early phase of subacute thyroiditis. J. Clin. Endocrinol. Metab., 44: 1107-1114, 1977.

16) 満間照典, 広岡 良文, 鰐部春松, 山内一征, 仁瓶禮之: 亜急性甲状腺炎にアスピリン又はプレドニソロン治療中の末梢甲 状腺ホルモンの変動, 最新医学, 32: 330-334, 1977.

17) 伴 良雄, 百渓尚子, 三村 孝, 西川義彦, 伊藤国彦：亜急性甲状腺炎の経過における下垂体甲状腺機能の変動について，内科, 39: 666一 671, 1977.

18) Yamamoto, M., Saito, S., Kaise, K., Kaise, N., Yoshida, K. and Yoshinaga, K.: Changes in thyroid hormones by treatment with aspirin and predonisolone in subacute thyroiditis with hyperthyroidism. Tohoku J. exp. Med., 127: 85-95, 1979.

19) 吉田克巳, 桜田俊郎, 海瀬信子, 海瀬和郎, 貴田岡博史, 深沢 洋, 山本蒔子, 斉藤慎太郎: 要急性 
甲状腺炎における free thyroxine および free 3，5，3'-triiodothyronine. 日内分泌会誌，56: 15271534, $1980 . \quad 20)$ Yoshida, K., Sakurada, T., Kaise, N., Kaise, K., Kitaoka, H., Fukazawa, H., Yamamoto, M., Saito, S. and Yoshinaga, K.: Serum free thyroxine and triiodothyronine concentrations in subacute thyroiditis. J. Clin. Endocrinol. Metab., 55: 185-188, $1982 . \quad 21)$ Volpé, R., Row, V.V. and Ezrin, C.: Circulating viral and thyroid antibodies in subacute thyroiditis. J. Clin. Endocrinol. Metab., 27: 1275-1284, 1967. 22) 深沢 洋, 桜田俊郎, 田村啓二, 山本蔚子, 吉田克巳, 貴田岡博史, 海瀬信子, 海瀬和郎, 鈴木道子, 斉藤慎太郎, 吉永 馨, 石田名香雄：覀急性甲状腺炎における免疫抑制酸性蛋白, 日 内分泌会誌, 58: 1005-1017, $1982 . \quad 23)$ Wall, J.R., Fang, S.L., Ingbar, S.H. and Bravermann, L.E.: Lymphocyte transformation in response to human thyroid extract in patients with subacute thyroiditis. J. Clin. Endocrinol. Metab., 43: 587-590, 1976.

24) Volpé, R.: Treatment of thyroiditis. Mod. Treat., 6: 474-496, 1969.

25) Torikai, T. and Kumaoka, S.: Subacute thyroiditis treated with salicylate: report of 5 cases. New Engl. J. Med., 259: 1265-1267, 1958.

26) Eylan, E., Zmucky, R. and Sheba, C.: Mumps virus and subacute thyroiditis. Evidence of a causal association. Lancet I: $1062-1063,1957 . \quad 27)$ Swann, N.H.: Acute thyroiditis: Five cases associated with adenovirus infection. Metabolism, 13: 908-910, 1964.

28) Saito, S.: Clinical studies of subacute thyroiditis. Gumma J. Med. Sci. 8(Suppl. 17), 1959. 29) Liberman, U., Djaldetti, M. and DeVries, A.: A case of herpangia, pleurodynia and subacute thyroiditis. Harefuah, 67: 342-345, 1964.

（受付日：59.6，16） 